\title{
Perencanaan dan Pengembangan Aplikasi Stok Barang dan Penjualan pada UPT. Kewirausahaan Menggunakan Barcode dan Smart Card (Studi Kasus UPT. Kewirausahaan Politeknik Negeri Tanah Laut)
}

\author{
Agustian Noor ${ }^{1}$, Herpendi ${ }^{2}$, Radna Nurmalina ${ }^{3}$ \\ Jurusan Teknik Informatika, Politeknik Negeri Tanah Laut \\ E-mail: *lagustiannoor@ymail.com, ${ }^{2}$ herpendi@politala.ac.id, \\ radnanurmalina@yahoo.co.id
}

\begin{abstract}
Abstrak - Penelitian ini secara umum bertujuan untuk menghasilkan sistem yang dapat mengelola data-data stok barang dan penjualan di UPT Kewirausahaan Politeknik Negeri Tanah Laut. Usulan penelitian ini difokuskan terlebih dahulu pada membangun aplikasi stok barang dan penjualan dengan menambah sentuhan teknologi barcode dan smart card yang mampu memberikan kemudahan dalam pengelolaan data barang. Saat ini stok barang dan penjulanan dilakukan secara manual dengan menulis di buku besar. Untuk mempermudah melakukan proses transaksi dan pengelolaan stok barang tersebut maka dibangun "Aplikasi Stok Barang dan Penjualan Pada Upt. Kewirausahaan Menggunakan Barcode dan Smart Card (Studi Kasus Upt. Kewirausahaan Politeknik Negeri Tanah Laut)". Aplikasi digunakan pada saat proses transaksi dan pengelolaan stok barang, dari proses barang masuk sampai barang keluar dengan metode yang digunakan yaitu mendekatkan atau meletakkan barcode pada kode barang dan smart card atau kartu RFID pada alat pembaca kartu RFID yang dimiliki pelanggan terdaftar, maka secara langsung aplikasi menerima data yang ada pada barcode dan kartu tersebut. Aplikasi ini, diharapkan pada tahun berikutnya dapat dikembangkan aplikasi pendukung lain guna dapat menghasilkan sistem informasi yang tepat guna, baik, dan terintegrasi untuk dapat menciptakan sebuah kampus cerdas.
\end{abstract}

Kata Kunci-Aplikasi, Barcode, Smart Card

\begin{abstract}
This research generally aims to produce a system that can manage the data of stock of goods and sales in UPT Kewirausahaan Politeknik Negeri Tanah Laut. The proposal of this research is focused on building the application of stock of goods and sales by adding a touch of barcode technology and smart card that can provide convenience in the management of goods data. Currently the stock of goods and sales done manually by writing in the ledger. To facilitate the process of transaction and stock management of goods is then built " Aplikasi Stok Barang dan Penjualan Pada Upt. Kewirausahaan Menggunakan Barcode dan Smart Card (Studi Kasus Upt. Kewirausahaan Politeknik Negeri Tanah Laut) ". The application is used during transaction processing and stock management, from the process of goods into the goods out with the method used is closer or put a barcode on the code of goods and smart card or RFID card on RFID card reader owned by registered customers, the application directly receive the existing data on the barcode and the card. This application, is expected in the next year can be developed other supporting applications in order to produce appropriate information system, good, and integrated to be able to create a smart campus.
\end{abstract}

Keywords - Application, Barcode, Smart Card

\section{PENDAHULUAN}

Ilmu pengetahuan dan teknologi (IPTEK) dewasa ini terus mengalami kemajuan yang pesat. Dapat dilihat dalam kehidupan sehari-hari, peralatan elektronik menjadi penunjang dalam menjalankan pekerjaan. Salah satu peralatan elektronik tersebut ialah komputer. Komputer saat ini banyak digunakan untuk menunjang aktifitas jual-beli, misalnya digunakan untuk transaksi penjualan, transaksi pembelian, transaksi pemesanan maupun untuk keperluan lainnya. 
Unit Pelaksana Teknis (UPT) Kewirausahaan Politeknik Negeri Tanah Laut adalah sebuah unit yang bergerak di bidang wirusaha yang bertujuan mewadahi minat dan bakat mahasiswa dalam bidang entrepreneurship. Kegiatan sehari-hari dari UPT Kewirausahaan adalah melaksanakan taransaksi jual-beli dengan para konsumen yang ada di lingkungan kampus Politeknik Negeri Tanah Laut. Proses jual-beli dilakukan dengan transaksi manual dan perekapan transaksi ditulis di buku harian. Menurut pengakuan anggota UPT Kewirausahaan bahwa sering terjadi kesalahan pencatatan transaksi yang berujung pada kesalahan perekapan data penjualan. Sehingga anggota yang bertugas harus melacaknya dengan membuka satu per satu transaksi dan menghitung sisa item barang yang ada dan ini dirasa kurang efektif.

Berdasarkan latar belakang yang telah diuraikan, maka penulis mengajukan penelitian dengan judul "Perencanaan dan Pengembangan Aplikasi Stok Barang dan Penjualan pada UPT. Kewirausahaan Menggunakan Barcode Smart Card (Studi Kasus UPT. Kewirausahaan Politeknik Negeri Tanah Laut)". Dengan adanya aplikasi ini diharapkan dapat mengatasi masalah yang dialami oleh UPT Kewirausahaan. Barcode Scanner dan RFID akan mempermudah setiap transaksi yang dilakukan yaitu hanya dengan menscan kode barang dan kartu RFID untuk identitas pembeli maka data akan tampil dilayar komputer. Setiap data transaksi tersimpan di database untuk mempermudah pelaporan.

\section{METODE PENELITIAN}

\subsection{Kerangka Penelitian}

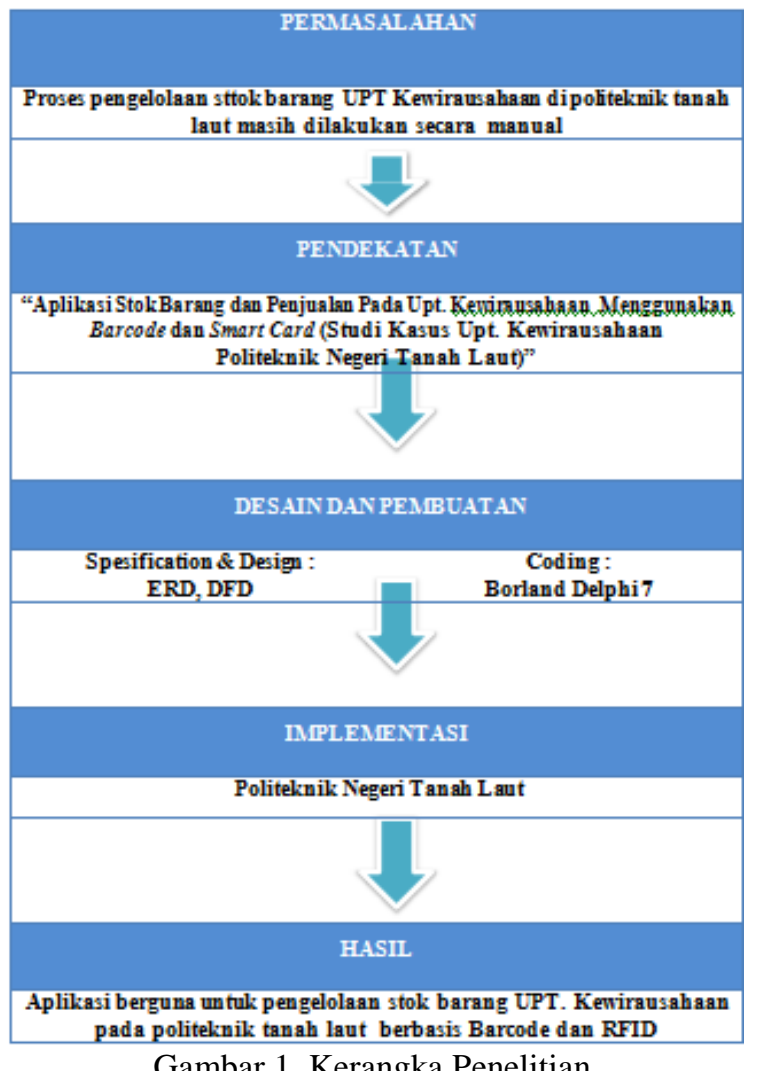

Gambar 1. Kerangka Penelitian berikut:

Pada Gambar 1 menjelaskan kerangka pada penelitian ini, yang terdiri dari langkah-langkah

1. Masalah: merupakan tahap identifikasi dan analisa yang dilakukan untuk kemudian ditentukan solusi akan masalah tersebut.

2. Pendakatan: merupakan tahap penentuan solusi untuk pemecahan masalah yang telah diidentifikasi

3. Pengembangan: merupakan tahap perancangan dan pengembangan system yang dibangun 
4. Penerapan: merupakan tahap penerapan dan pengujian system yang dibangun

5. Hasil: terciptanya sebuah sistem sebagai solusi dari permasalahan yang diangkat.

\subsection{Metode Pengembangan Sistem}

Prototype didefinisikan sebagai salah satu versi dari sebuah sistem potensial yang memberikan ide bagi para pengembang dan calon pengguna, bagaimana sistem akan berfungsi dalam bentuk yang telah selesai.

Pembuatan Aplikasi Monitoring Hasil Studi Mahasiswa Tenik Informatika Politeknik Negeri Tanah Laut Berbasis Web Mobile dan SMS Gateway ini menggunakan metode pengembangan Prototype dikarenakan sesuai dengan proses pembangunan sistem yang ada.

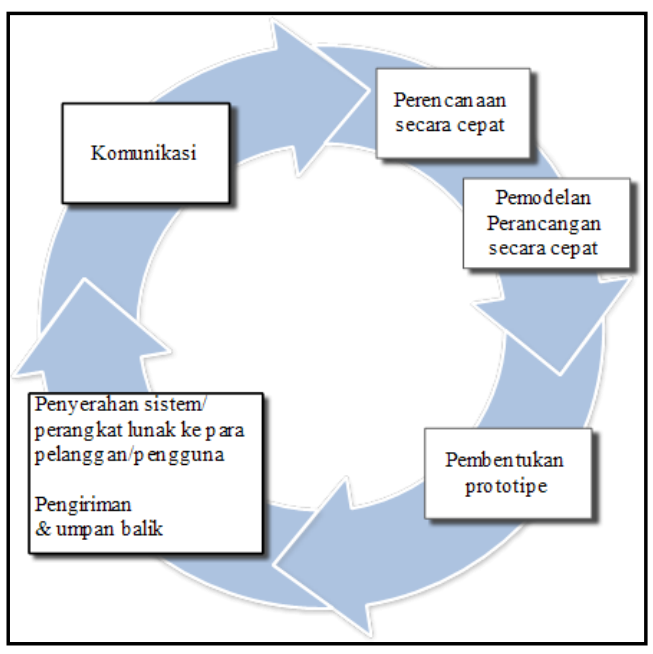

Gambar 2 Metode Pengembangan Sistem

Sumber : (Pressman, 2010)

Pada Gambar 2 menggambarkan:

1. Komunikasi yaitu analisis terhadap kebutuhan pengguna.

2. Perencanaan secara cepat, yaitu pembuatan desain secara umum untuk selanjutnya dikembangkan kembali.

3. Pemodelan Perancangan secara cepat yatu perancangan sistem untuk mengembangkan prototipe dengan menggunakan Data Flow Diagram sebagai dasar perancangan sistem.

4. Pembentukan prototipe, yaitu pembuatan perangkat prototipe termasuk pengujian dan penyempurnaan.

5. Penyerahan sistem kepada pengguna apakah sistem dapat diterima. Produksi akhir, yaitu memproduksi perangkat secara benar sehingga dapat digunakan oleh pengguna jika tidak maka akan diulangi pada tahap 4 dan 5 .

\subsection{Metode Pengumpulan Data}

Metode pengumpulan data dilakaukan dengan 3 (tiga) cara yaitu:

a. Metode Observasi

Proses pengamatan objek penelitian secara langsung di lapangan pada saat melakukan riset. Kegiatan ini diperlukan untuk melihat kondisi riil di lapangan berkenaan dengan sistem yang akan dibangun. Dengan observasi akan diketahui kebutuhan-kebutuhan yang diperlukan oleh calon pengguna.

b. Metode Studi Pustaka

Metode studi pustaka atau library research yang dilakukan oleh penulis dengan cara membaca buku literatur, menganalisa, menyimpulkan, mengutip bacaan-bacaan dari artikel maupun jurnal yang ada di internet serta mempelajari dokumen-dokumen yang ada sesuai dengan objek pengamatan.

c. Metode Wawancara 
Suatu bentuk metode riset dengan mengajukan beberapa pertanyaan terhadap narasumber pada objek penelitian penulis. Pertanyaan berkaitan dengan sistem yang akan dibangun.

\section{A. Sistem yang Berjalan}

\section{HASIL DAN PEMBAHASAN}

UPT. Kewirausahaan dalam melakukan pencatatan stok barang dengan menggunakan buku. Begitu pula dengan transaksi penjulan kepada konsumen masih dilakukan secara manual dengan menulisnya di kertas. Belum ada sebuah sistem terkomputerisasi dalam kegiatan pencatatan dan transaksi penjulaan yang dilakukan oleh UPT. Kewirausahaan Politeknik Negeri Tanah laut. Dengan sistem yang sedang berjalan ini tentu akan memperlambat kinerja dibandingkan dengan menggunakan sistem yang terkomputerisasi.

\section{B. Sistem yang Diusulkan}

Berdasarkan dari beberapa kelemahan sistem yang sekarang berjalan, yaitu masih banyak penggunaan kertas untuk pembuatan daftar absensi, tidak adanya pencatatan waktu dalam proses absensi, pemakaian waktu yang lebih lama untuk proses pendataan, pengolahan data dan pembuatan laporan, belum dipakainya daftar stok barang untuk mengetahui tingkat kedisiplinan mahasiswa, maka rancangan sistem yang akan dibangun diharapkan dapat memberikan informasi dan kemudahan diantaranya:

1. Mengurangi penggunaan kertas dalam proses stok barang.

2. Mampu mencatat waktu terjadinya proses absensi.

3. Mempersingkat waktu dalam proses pendataan, pengolahan dan pembuatan laporan.

4. Menggunakan data absensi untuk menghasilkan penilaian kedisiplinan mahasiswa.

5. Dapat membantu penyimpanan data supaya lebih terjaga dalam database.

\section{Implementasi Sistem}

1. Halaman Menu Utama

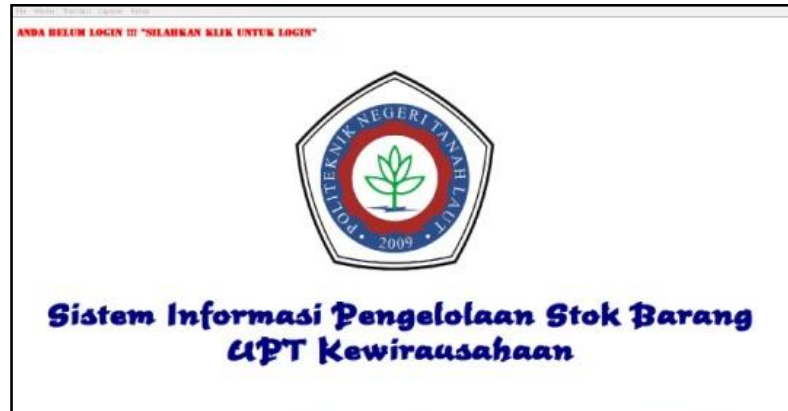

Gambar 4. Menu Utama

Gambar 4 merupakan gambar halaman menu utama yang menampilkan halaman utama dari aplikasi yang menampilkan menu - menu dalam aplikasi.

2. Halaman Login

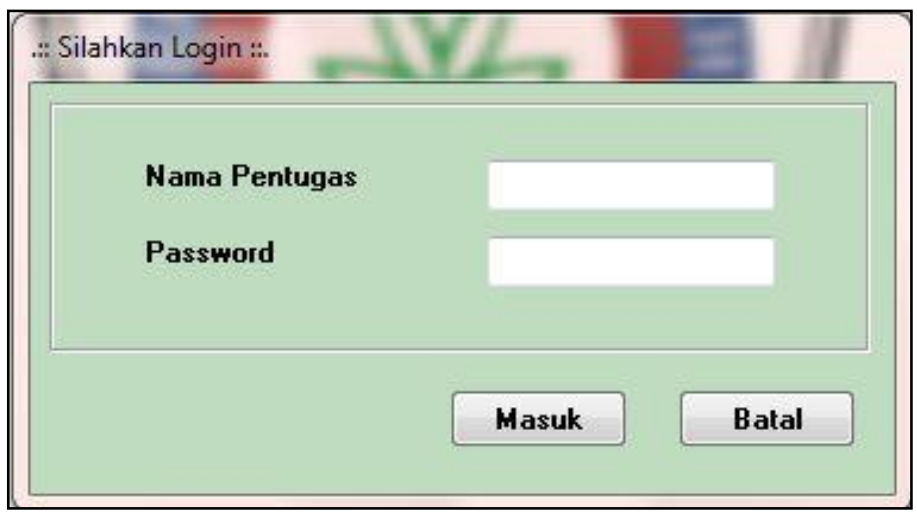

Gambar 5. Halaman Login 
Gambar 4.8 merupakan gambar Apabila username dan password yang dimasukkan salah, maka akan muncul peringatan "username atau password salah" dan akan kembali ke menu login untuk melakukan login kembali, dan apabila login berhasi dilakukan maka akun tersebut dapat mengakses aplikasi.

\section{Form Transaksi Penjualan}

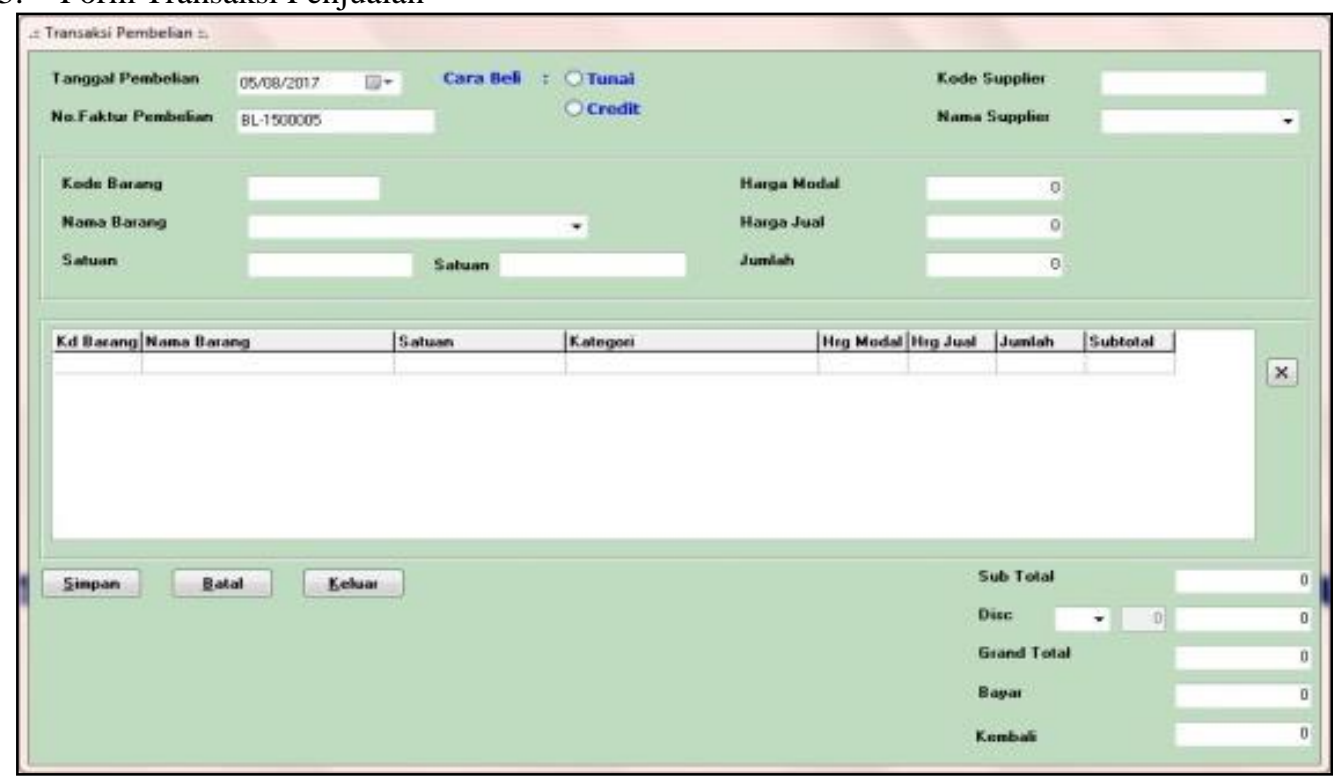

Gambar 6. Form Transaksi Penjualan

Gambar 6 menunjukkan tampilan Form Transaksi Penjualan. Form ini berfungsi saat melakukan penjualan. Hanya dengan memindai kode barang dengan barcode scanner maka data barang akan muncul sehingga sangat mempermudah dalam transaksi penjualan.

\section{Pengujian Sistem}

Pengujian sistem dilakukan oleh:

1. Herpendi, M.Kom

Dosen pemrograman di Politeknik Negeri Tanah Laut dengan fokus keilmuan pada Software Engineering (Rekayasa Perangkat Lunak)

2. Khairul Anwar Hafizd, M.Kom

Dosen pemrogrman di Politeknik Negeri Tanah Laut dengan fokus keilmuan pada Software Engineering (Rekayasa Perangkat Lunak) dan Sistem Informasi Bisnis

Tabel 1. Pengujian Black Box

\begin{tabular}{|c|l|c|l|}
\hline No & \multicolumn{1}{|c|}{ Skenario Pengujian } & $\begin{array}{c}\text { Hasil } \\
\text { Pengujian }\end{array}$ & \multicolumn{1}{|c|}{ Penguji } \\
\hline 1 & Fungsi Login & Berhasil & Herpendi \\
\hline 2 & Fungsi Tambah Data Barang & Berhasil & Herpendi \\
\hline 3 & Fungsi Edit Data Barang & Berhasil & Herpendi \\
\hline 4 & Fungsi Hapus Data Barang & Berhasil & Herpendi \\
\hline 5 & Fungsi Tambah Data Satuan & Berhasil & Herpendi \\
\hline 6 & Fungsi Edit Data Satuan & Berhasil & Herpendi \\
\hline 7 & Fungsi Hapus Data Data Satuan & Berhasil & Herpendi \\
\hline 8 & Fungsi Tambah Data Ketegori & Berhasil & Herpendi \\
\hline 9 & Fungsi Edit Data Kategori & Berhasil & Herpendi \\
\hline 10 & Fungsi Hapus Data Kategori & Berhasil & Herpendi \\
\hline 11 & Fungsi Tambah Data Pelanggan & Berhasil & Herpendi \\
\hline 12 & Fungsi Edit Data Pelanggan & Berhasil & Herpendi \\
\hline 13 & Fungsi Hapus Data Pelanggan & Berhasil & Herpendi \\
\hline 14 & Fungsi Tambah Data Supplier & Berhasil & Herpendi \\
\hline
\end{tabular}




\begin{tabular}{|c|l|c|l|}
\hline No & \multicolumn{1}{|c|}{ Skenario Pengujian } & $\begin{array}{c}\text { Hasil } \\
\text { Pengujian }\end{array}$ & \multicolumn{1}{|c|}{ Penguji } \\
\hline 15 & Fungsi Edit Data Supplier & Berhasil & Herpendi \\
\hline 16 & Fungsi Hapus Data Supplier & Berhasil & Herpendi \\
\hline 17 & Fungsi Tambah Data Karyawan & Berhasil & Herpendi \\
\hline 18 & Fungsi Edit Data Karyawan & Berhasil & Herpendi \\
\hline 19 & Fungsi Hapus Data Karyawan & Berhasil & Herpendi \\
\hline 20 & Fungsi Tambah Data Petugas & Berhasil & Herpendi \\
\hline 21 & Fungsi Edit Data Petugas & Berhasil & Herpendi \\
\hline 22 & Fungsi Hapus Data Petugas & Berhasil & Herpendi \\
\hline 23 & Fungsi Tambah Data Transaksi Beli & Berhasil & Khairul Anwar Hafizd \\
\hline 24 & Fungsi Tambah Data Transaksi Jual & Berhasil & Khairul Anwar Hafizd \\
\hline 25 & Fungsi Tambah Data Hutang & Berhasil & Khairul Anwar Hafizd \\
\hline 26 & Fungsi Tambah Data Piutang & Berhasil & Khairul Anwar Hafizd \\
\hline 27 & Fungsi Logout & Berhasil & Herpendi \\
\hline
\end{tabular}

\section{SIMPULAN}

Aplikasi Stok Barang dan Penjualan berhasil dibangun untuk menunjang kinerja UPT. Kewirausahaan. Dengan aplikasi ini proses transaksi penjualan dilakukan secara terkomputerisasi hanya dengan memindai barang yang akan dijual. Stok barang secara otomatis mengalamai pengurangan setiap terjadinya transaksi penjualan sehingga mempermudah dalam pengelolaannya. Data pelanggan disimpan dalam Smart Card untuk mempermudah proses pencatatan yaitu hanya dengan memindai Smart Card maka data akan tampil di aplikasi. Dengan aplikasi ini pengelolaan data lebih teratur sehingga proses pelaporan juga akan menjadi lebih baik.

\section{SARAN}

Saran penulis untuk peneliti selanjutnya ialah aplikasi bisa dikembangkan menjadi clientserver sehingga perkembangan transaksi tetap bisa dipantau oleh ketua UPT. Kewirausahaan secara real-time kapanpun dan dimanapun dengan koneksi internet.

\section{DAFTAR PUSTAKA}

[1] Alam, M. A. (2003). Belajar Sendiri Mengolah Database Dengan Borland Delphi 7. Jakarta: PT. ELEX MEDIA KOMPUTINDO.

[2] Al-fatta, H. (2007). Analisis \& Perancangan Sistem Informasi Untuk Keunggulan Bersaing Perusahaan Organisasi Modern. Yogyakarta: CV. ANDI OFFSET.

[3] Al-fatta, H. (2009). Rekayasa Sistem Pengenalan Wajah. Yogyakarta: CV. Andi OFFSET. Ali, M. (2007). Ilmu dan Aplikasi Pendidikan Bagian I : Ilmu Pendidikan Teoretis. Bandung : PT. IMPERIAL BAKTI UTAMA.

[4] Husni, 2004. Pemrograman Database dengan Delphi. Yogyakarta : Graha Ilmu. Kuswayatno, L. (2006). Mahir dan Terampil Berkomputer. Bandung : GRAFINDO MEDIA PRATAMA.

[5] Miles, S. B. (2008). RFID Technology and Applications. New York: Cambridge University Press.

[6] Pramana, H. W. (2005). Kunci Sukses Aplikasi Penjualan Berbasis Access 2003. Jakara: Media Komputindo.

[7] Pressman. (2010). Rekayasa Perangkat Lunak. Yogyakarta: Andi.

[8] Yuhefizard, S. (2008). Database Management Menggunakan Microsoft Access 2003. Jakarta: PT. Elex Media Komputindo. 